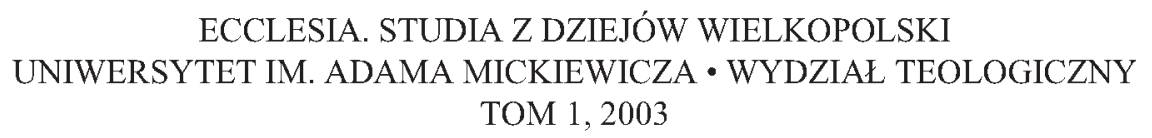

ECCLESIA. STUDIA Z DZIEJÓW WIELKOPOLSKI

UNIWERSYTET IM. ADAMA MICKIEWICZA • WYDZIAL TEOLOGICZNY

TOM 1,2003

KRZYSZTOF KACZMAREK

\title{
Konwent dominikanów poznańskich w średniowieczu
}

\begin{abstract}
I
Charakterystyczną cechą współczesnej historiografii poświęconej dziejom średniowiecznych zakonów jest rosnący nacisk na rozpoznanie związków łączących te wspólnoty ze światem laików. Historycy starają się pokazać różnego typu powiązania konwentów z ludźmi świeckimi, zamieszkującymi otoczenie domów zakonnych: analizuja problematykę związaną z rekrutacją do średniowiecznych klasztorów i odtwarzają przy tej okazji środowisko społeczne, z którego wywodzili się nowicjusze oraz ich rodzinne powiązania, podejmują zagadnienie związków gospodarczych i kulturalnych klasztorów, zastanawiają się także nad religijnymi wpływami konwentu i oddziaływaniem zakonników na życie wewnętrzne i poglądy ludzi poddanych ich oddziaływaniu. Bardzo chętnie również podejmowane są badania samej społeczności klasztornej - historycy analizują jej skład osobowy, narodowościowy i społeczny, odtwarzają zasięg prowadzonej przez konwenty rekrutacji, badają poziom wykształcenia braci itp. ${ }^{1}$

\footnotetext{
${ }^{1}$ Ostatnio na ten temat J. R a j m a n, Średniowieczne klasztory na Górnym Ślasku. Problem rekrutacji $i$ zasięg spolecznego oddzialywania, w: Klasztor w spoleczeństwie średniowiecznym i nowożytnym, pod red. M. Derwicha i A. Pobóg-Lenartowicz, Opole - Wroclaw 1996, s. 67-73; P. W is z e w s k i, Legnickie opactwo benedyktynek Bożego Ciała w spoteczeństwie ślaskim (13481538), w: Klasztor w spoteczeństwie, s. 75-90; G. W a s, Franciszkanie w spoteczenistwie Ślaska w średniowieczu i dobie nowożytnej, w: Klasztor w spoteczeństwie, s. 126; M. M a c i s z e w s k a, Klasztor bernardyński w spoteczeństwie polskim w latach 1435-1530, w: Klasztor w spoteczeństwie, s. 153; eadem, Klasztor bernardyński w spoleczeństwie polskim 1453-1530, Warszawa 2001; eadem, Klasztor bernardyński w pejzażu przedmieść późnośredniowiecznych miast i miasteczek Królestwa Polskiego i Wielkiego Księstwa Litewskiego, w: Ecclesia et civitas. Kościót $i$ życie religijne w mieście średniowiecznym, pod red. H. Manikowskiej i H. Zaremskiej, Warszawa 2002, s. 129$139 ; \mathrm{K}$. K a c z m a r e k, Spoleczeństwo średniowiecznego miasta wobec klasztoru franciszkanów. Przyktad Zgorzelca, w: Klasztor w mieście średniowiecznym i nowożytnym, pod red. M. Derwicha i A. Pobóg-Lenartowicz, Wroclaw - Opole 2000, s. 521-532; P. O 1 i ń s k i, Kontakty kartuzów
} 
Rozwój tych badań związany jest z intensywnym wykorzystywaniem przez historyków wszelkiego typu źródeł proweniencji zakonnej, które pozwalają oświetlić zamieszkujące klasztory społeczności. Do przekazów takich zaliczyć należy całą dyplomatyczną produkcję skryptoriów, klasztorne kroniki, roczniki i kalendarze, akta różnego szczebla kapituł, a także źródła memoratywne: nekrologi i średniowieczne libri mortuorum oraz tak zwane ksiegi profesji - spisy osób wstępujących do klasztorów i składających przy tej okazji zakonne śluby. Przechowane w nich informacje dają historykom nieocenione wprost możliwości badań nad szeroko rozumianą familiq klasztorną: samymi zakonnikami, ich służbą (konwersami), fundatorami i dobrodziejami klasztorów, kregiem rodzinnym braci - jednym słowem wszystkimi, którzy należeli do wspólnoty modlitewnej klasztoru i dzięki wstawiennictwu konwentu mieli udział w jego duchowych łaskach ${ }^{2}$.

W porównaniu z liczbą klasztorów różnych reguł, jakie w średniowieczu ufundowano na ziemiach polskich przekazów tych nie ma, niestety, wiele. Zwyczajne ich zużycie, a także straty, jakie poniosły archiwa i biblioteki poszczególnych konwentów w wyniku różnych wojen, grabieży oraz kasat klasztorów sprawiły, że do naszych czasów przetrwał tylko bardzo skromny procent spisanych w dawnych wiekach tekstów. Jeszcze mniej zostało zaś ogłoszonych drukiem. Co ciekawe do naszych czasów zachowało się i zostało wydanych znacznie więcej dokumentów, kronik, kalendarzy i mortuarzy spisanych w klasztorach mniszych i kanonickich, aniżeli w domach mendykanów, w tym również szczególnie nas interesujących dominikanów3 ${ }^{3}$ Jeśli chodzi o konwenty Braci Kaznodziejów, to spośród kilkudziesięciu klasztorów tej reguły, jakie w okresie wieków średnich istniały na ziemiach polskich zachowało się i zostało wydanych drukiem niewiele tego typu zabytków. Pod koniec XIX Heinrich Zeissberg wydał średniowieczne fragmenty mortuarza spisanego w krakowskim klasztorze św. Trójcy", a Wojciech Kętrzyń-

z Raju Maryi z mieszczaństwem gdańskim w średniowieczu, w: Klasztor w mieście, s. 123-134; M. C e t w i ń s k i, Klasztor w oczach sąsiadów. Ze studiów nad Księga Henrykowskq, w: Cystersi w spoleczeństwie Europy Środkowej, pod red. A. M. Wyrwy i J. Dobosza, Poznań 2000, s. 696704; P. W i s z e w s k i, Cysterki trzebnickie w spoleczeństwie ślaskim (czwarta ćwierć XIII wieku - pierwsza potowa XIV wieku), w: Cystersi w spoteczeństwie, s. 705 - 718; G. W a s, Klasztory franciszkańskie w miastach ślaskich i górnolużyckich XIII-XVI wieku, Wrocław 2000.

${ }^{2}$ Zob. M. K a c z m a r e k, Średniowieczny konwent klasztoru kamienieckiego $w$ świetle wlasnego nekrologu, w: Wieki stare i nowe, t. 2, pod red. I. Panica i M. W. Wanatowicz, Katowice 2001, s. 63-71; M. S t a r n a w s k a, Nekrolog krzyżowców z czerwona gwiazdq: źródlo do poznania środowiska zakonu i jego kontaktów, w: Klasztor w spoleczeństwie, s. 219; K. K a c z$\mathrm{m}$ a r ek, Nekrolog opactwa cystersów w Paradyżu (w druku).

${ }^{3} \mathrm{~J}-\mathrm{L}$. L e m a ît r e, M. D e r w i c h, Pour un répetoire des obituares polonais, w: Śmierć w dawnej Europie. Zbiór studiów, pod red. M. Derwicha, Wrocław 1997, s. 29-43.

${ }^{4} \mathrm{H}$. Z e i s s b e r g, Kleinere Geschichtsquellen Polens im Mittelalter, „Archiv für Österreichische Geschichte", 55 (1877), s. 136-167. 
ski opublikował nekrolog dominikanów lwowskich ${ }^{5}$; nieco później natomiast -krótko przed wybuchem II wojny światowej - ksiądz Kamil Kantak wydał zawierający wspomnienia o zmarłych członkach konwentu Kalendarz dominikanów poznańskich ${ }^{6}$.

Do naszych czasów nie zachowały się niestety średniowieczne ksiegi dominikańskich profesji. Znamy jednak przykłady podobnych zabytków z wieku XVI i domyślamy się, że praktyka ich prowadzenia ma starą tradycję ${ }^{7}$. Uprawnione jest chyba podejrzenie, że spisy wstępujących do konwentów nowicjuszy były prowadzone we wszystkich klasztorach od poczattku ich istnienia - wymagaly tego względy porządkowe oraz konieczność przestrzegania ustawodawstwa zakonnego, które zabraniało braciom opuszczania ich macierzystych konwentów i przenoszenia się do innych domów zakonnych bez zgody przełożonych. O tym, że prowadzenie takich wykazów było powszechnie praktykowane mogą świadczyć fragmenty podobnych spisów z końca XV wieku, zachowane w rękopisach pozostałych po wrocławskim klasztorze dominikanów ${ }^{8}$.

Podniesiony wyżej fakt niezachowania się do naszych czasów średniowiecznych ksiagg profesji i dostępu historyków do znikomej w sumie liczby nekrologów poteguje trudności w badaniu dawnych społeczności klasztornych. Próbując bowiem odtworzyć stany osobowe poszczególnych konwentów na przestrzeni kolejnych lat jesteśmy $w$ istocie zdani na informacje wyrywkowe i w dużej mierze przypadkowe. Dokumenty, kroniki klasztorne, akta kapituł generalnych i prowincjalnych (jeśli dany zakon je posiada) są dla interesujących nas badań na pewno użyteczne, ale nie ulega watpliwości, że nie mogą one w pełni zastąpić samych wykazów wstępujących do klasztoru nowicjuszy i spisów tych zakonników, którzy już zmarli. Badanie społeczności klasztornych mendykantów utrudnia dodatkowo

${ }^{5}$ Liber mortuorum monasterii Leopoliensis sancti Dominici, wyd. W. Kętrzyński, w: Monumenta Poloniae Historica, t. 5, Lwów 1888, s. 537-561.

${ }^{6}$ K. K a n t a k, Kalendarz dominikanów poznańskich, „Kronika Miasta Poznania”, 13 (1935), s. 398-406. Autopsja rękopiśmiennego oryginału „Kalendarza” przechowywanego w Archiwum Archidiecezjalnym w Gnieźnie (sygn. Ms 203) przekonuje, że wydanie księdza Kamila Kantaka zawiera kilkadziesiąt błędów - nie uwzględniono w nim wszystkich adnotacji o zmarlych, jakie występują w źródle, blędnie rozwiązano niektóre imiona i bez żadnego uzasadnienia i poinformowania o tym zabiegu czytelnika skrócono niektóre zapisy „Kalendarza”. W tej sytuacji, przypominając o istnieniu publikacji ks. Kantaka, postulujemy jednocześnie gruntownie poprawioną reedycję wydanego przezeń zabytku.

${ }^{7}$ Metrica Fratrum Professorum in Conuentu Posnaniensi S. Dominici Ordinis Praedicatorum Ab Anno Domini 1576 usque ad annum 1632 - Archiwum Archidiecezjalne w Poznaniu, sygn. AZ 5/4, Metrica Conventus Lublinensis in qua nomina omnium fratrum Ordinis Praedicatorum [...] Ab Anno Domini 1587 describantur ex antiquo originali in novu transala et corecta [...] Anno 1798 - Archiwum Archidiecezjalne w Lublinie, sygn. Rep. 60 A 246.

${ }^{8}$ Biblioteka Uniwersytecka we Wrocławiu, sygn. rkp. IV Q 191. 
także znany powszechnie fakt olbrzymiej mobilności tych środowisk. Wiadomo, że w przeciwieństwie do zakonów mniszych we wspólnotach żebraczych nie obowiązywała zasada statości miejsca (stabilitas loci), a bracia bardzo często zmieniali przynależność konwentualną, wędrowali pomiędzy klasztorami w obrębie danej prowincji zakonnej, a także poza nią. Taką aktywność wymuszały ich zajęcia duszpasterskie, głoszenie kazań, kwesta, obowiązek studiów, jak również działalność inkwizycyjna. Fakt nieustannej wędrówki mendykantów sprawia jednak, że trudno nam dzisiaj odtworzyć stany osobowe poszczególnych klasztorów w konkretnym przedziale czasu.

Ze wskazanych tu powodów (niedostatków źródeł i specyfiki życia zakonów żebraczych) także i nasze rozważania o konwencie poznańskich dominikanów w okresie od XIII do końca XVI wieku muszą być skażone trudną do oszacowania skalą błędu. Mając tego świadomość podejmujemy jednak próbę oświetlenia tego środowiska. Skłaniają nas do tego dwa powody: 1/ w wydanych dotą pracach poświęconych temu klasztorowi problem ten został przedstawiony w sposób - naszym zdaniem - niezadowalający; 2/ w dotychczasowych badaniach nad poznańskimi dominikanami nie wykorzystano wielu ważnych źródeł; dotarcie do nich i analiza ich zawartości może zaś w znaczącym stopniu poszerzyć naszą wiedzę o zespole ludzi, którzy na przestrzeni kilku wieków zamieszkiwali poznański klasztor Braci Kaznodziejów.

\section{II}

Podejmując próbę przedstawienia konwentu dominikanów z Poznania należy przybliżyć dostępną analizie podstawę źródłową naszych rozważań. Do najważniejszych materiałów oświetlających dzieje klasztoru poznańskiego, które zostały wydane drukiem zaliczamy: pewną liczbę opublikowanych w kodeksach dyplomatycznych dokumentów ${ }^{9}$, wspomniane wyżej nekrologi i kalendarze ${ }^{10}$, następnie akta kapituł generalnych i prowincjalnych dominikanó $w^{11}$, a także tak zwany Zbiór formul zakonu dominikańskiego prowincji polskiej ${ }^{12}$. Z wymienionych tu przekazów z pewnością najcenniejsze są zachowane do naszych czasów protokoły z posiedzeń kapituł polskiej prowincji Ordo Praedicatorum. Nie znamy ich jednak, niestety, zbyt

${ }^{9}$ Kodeks Dyplomatyczny Wielkopolski, t. 1-11, Poznań 1877-1999 (cyt. dalej: KDW).

${ }^{10}$ Zob. wyżej - przypisy 4, 5 i 6.

${ }^{11}$ Acta Capitulorum Generalium Ordinis Praedicatorum, t. 1-3, wyd. B. M. Reichert, Romae 1898-1900 (Monumenta Ordinis Praedicatorum Historica, t. 3, 4 i 8); Acta Capitulorum Provinciae Poloniae Ordinis Praedicatorum, vol. 1, Romae 1972 (cyt. dalej: Akta); P. K i e 1 a r, Organizacja szkolnictwa dominikańskiego w XIV wieku, „Studia Philosophiae Christianae”, 5 (1969), nr 1. s. 304-318 (cyt. dalej: K i e 1 a r).

${ }^{12}$ Zbiór formul Zakonu Dominikańskiego prowincji polskiej z lat 1338-1411, oprac. i wyd. J. Woroniecki i J. Fijałek, „Archiwum Komisji Historycznej”, 12 (1919-1938), s. 219-430 (cyt. dalej Zbf). 
wiele. Nie zachowały się one w ogóle dla wieku XIII; ze stulecia XIV przetrwały (i to w uszkodzonych fragmentach) protokoły zaledwie dwóch kapituł prowincji polskiej; z wieku XV zaś znamy ustawy z dziewięciu posiedzeń władz prowincji; pełniejszy ich wykaz zachował się dopiero dla stuleci nowożytnych.

Ten skromny jak widać zasób materiałów wydanych drukiem wydatnie uzupełniają liczne teksty oświetlające dzieje poznańskich dominikanów, które do tej pory nie zostały opublikowane i pozostają pod postacią rękopisów w zbiorach różnych archiwów i bibliotek. W Archiwum Państwowym w Poznaniu znajduje się liczący 220 jednostek archiwalnych zbiór akt pozostałych po interesującym nas klasztorze. Odnajdujemy wśród nich około 70 dyplomów z XIII-XIX wieku, dwa sumariusze dokumentów klasztornych, dotyczące dominikanów wyciagi z ksiąg ziemskich, grodzkich, radzieckich, konsystorskich i ławniczych, pochodzacy z końca XVIII wieku nekrolog konwentu, testamenty oraz akta podatkowe klasztoru od XVI do XIX wieku ${ }^{13}$. O wiele mniejszy zbiór materiałów podominikańskich z Poznania posiada miejscowe Archiwum Archidiecezjalne. Jedynym praktycznie, choć bardzo interesującym, zabytkiem jest wspomniana wyżej Metryka konwentu - spis i charakterystyka ponad 2000 osób, które wstapily do klasztoru dominikanów w Poznaniu w latach 1576-1815 ${ }^{14}$. Charakteryzując rękopiśmienną spuściznę oświetlającą dzieje ich konwentu należy jeszcze dodać przechowywany w Archiwum dominikańskiego klasztoru św. Trójcy w Krakowie kopiarz przywilejów klasztornych, zawierający regesty i odpisy dokumentów, dotyczące braci wypisy z ksiag ziemskich poznańskich ${ }^{15}$, a także znajdujący się w Bibliotece Kórnickiej XVII-wieczny rękopis De rebus provinciae Poloniae ordinis praedicatorum, pióra dominikanina Ludwika Teleżyńskiego ${ }^{16}$.

W odniesieniu do konwentu dominikanów poznańskich omówione wyżej przekazy wykorzystywano dotąd w stopniu bardzo ograniczonym - w porównaniu z innymi domami zakonnymi należącymi do średniowiecznej prowincji polskiej Ordo Praedicatorum literatura poświęcona temu klasztorowi jest bardzo skromna. Konwent ten nie doczekał się dotąd monograficznego opracowania, niewiele jest także poświęconych mu rozpraw analitycznych i drobniejszych przyczynków. Przedwojenne prace księdza Kamila Kantaka ${ }^{17}$, zarys dziejów klasztoru pióra ojca

\footnotetext{
${ }^{13}$ Archiwum Państwowe w Poznaniu, sygn. Dominikanie Poznań 1-220 (cyt. dalej: APP).

${ }^{14}$ Zob. wyżej - przypis $\mathrm{nr} 7$.

${ }^{15}$ Copiarium privilegiorum et aliorum documentorum Conventus Posnaniensis sancti Dominici Ord[inis] Praedicatorum ab anno 1244-1858 - Archiwum Klasztoru Dominikanów w Krakowie, sygn. Pzd 1 (cyt. dalej: CPCP).

${ }^{16}$ L. T e 1 e ż y ń s k i, De rebus Provinciae Poloniae S. Hyacinthi Ord[inis] Praedicatorum - Biblioteka Kórnicka, sygn. rkp I F 93 (cyt. dalej: T e 1 e ż y h́ s k i).

${ }^{17} \mathrm{~K} . \mathrm{K}$ a n t a k, Przyczynki do dziejów dominikanów poznańskich, „Kronika Miasta Poznania", 5 (1927), s. $867-874$ (cyt. dalej: KMP); idem, Dalsze przyczynki do dziejów dominikanów poznańskich, KMP 8 (1930), s. 335-342.
} 
Jana A. Spieża ${ }^{18}$ oraz gruntowne, oparte o rękopiśmienny materiał źródłowy, opracowania autorstwa Jacka Wiesiołowskiego ${ }^{19}$ - to najważniejsze z prac dotyczacych historii klasztoru Braci Kaznodziejów założonego w połowie XIII wieku w poznańskim grodzie. Wiadomości o zakonnikach tego konwentu odnajdujemy również w opracowaniach Jerzego Korolca ${ }^{20}$, Jerzego Kłoczowskiego ${ }^{21}$ i Wacława Bucichowskiego ${ }^{22}$, poświęconych średniowiecznym lektorom i studentom z polskiej prowincji dominikanów.

Właściwie żadna z wymienionych publikacji nie jest poświęcona w całości charakterystyce zespołu braci tworzących na przestrzeni kolejnych lat poznański konwent, choć przyznać trzeba, że w pracach K. Kantaka i J. Wiesiołowskiego odnajdujemy najwięcej interesujacych informacji na ten temat. Pierwszy z wymienionych autorów wykorzystał nieznane szerzej w jego czasach ustawy kapituł polskiej prowincji zakonu z XVI wieku, drugi zaś na wielką skalę (i ze znakomitym skutkiem) siegnął do krakowskich archiwaliów - znajomość tych źródeł pozwoliła obu autorom podać szereg ciekawych wiadomości na temat poznańskich dominikanów. W ich pracach spotykamy dość liczne grono wymienionych z imienia zakonników wraz z przypisanymi im urzędami klasztornymi. Odnajdujemy w nich także wiele cennych uwag dotyczących kontaktów, jakie ludzie ci utrzymywali ze świeckim otoczeniem konwentu. Na podstawie badań obu wzmiankowanych wyżej autorów można wyciagnąc wniosek o miejskim pochodzeniu większości z nich. Konwent rekrutował nowicjuszy w swym najbliższym otoczeniu wśród poznańskich mieszczan. Ludzie ci, zasilając zespół braci zamieszkujący klasztor dominikański, wchodzili doń razem ze swoimi dotychczasowymi życiowymi doświadczeniami, ukształtowanym przez wychowanie w rodzinie systemem

${ }^{18}$ J. A. S p i e ż, Dominikanie w Poznaniu, w: Poznańscy dominikanie, oprac. T. Dostatni, Poznań 1997, s. 5-18.

${ }^{19} \mathrm{~J} . \mathrm{W}$ i e s i o 1 o w s k i, Dominikanie w miastach wielkopolskich w okresie średniowiecza, w: Studia nad historia dominikanów w Polsce 1222-1972, t. I, pod red. J. Kloczowskiego, Warszawa 1975, s. 195-269; idem, Klasztory średniowiecznego Poznania, w: Poczqtki i rozwój starego miasta w Poznaniu $w$ świetle badań archeologicznych $i$ urbanistyczno - architektonicznych, pod red. W. Błaszczyka, Warszawa - Poznań 1977, s. 405-419; i d e m, Kultura i spoteczeństwo w późnym średniowieczu, w: Dzieje Poznania, t. 1, cz. 1, pod red. J. Topolskiego, Warszawa Poznań 1988, s. 315-316.

${ }^{20} \mathrm{~J} . \mathrm{B} . \mathrm{K}$ o $\mathrm{r}$ o 1 e c, Lista lektorów dominikańskich prowincji polskiej w XIII-XIV wieku. „Materiały i Studia Zakładu Historii Filozofii Starożytnej i Średniowiecznej”, 2 (1962), s. 196-213 (cyt. dalej: MSZHFSS, Korolec I); i d e m, Lista lektorów i szkót dominikańskich w Polsce XV wieku, MSZHFSS 4 (1965), s. 276-333 (cyt. dalej K o r o l e c II).

${ }^{21}$ J. K 1 o c z o w s k i, Ze zwiazków Polski z krajami zachodnimi u schytku średniowiecza. Studia zagraniczne dominikanów prowincji polskiej, w: Polska w Europie, Lublin 1968, s. 109-135 (cyt. dalej: K $10 \mathrm{c} \mathrm{z}$ o w s k i).

${ }^{22} \mathrm{~W}$. B u c i c h o w s k i, Lista lektorów dominikańskich prowincji polskiej od erygowania prowincji (1225) do roku 1525, „Przegląd Tomistyczny”, 6-7 (1997), s. 45-231 (cyt. dalej: B u c i chowski). 
wartości i przy zachowaniu ścisłych niekiedy związków ze swoimi najbliższymi, czy szerzej - całym kręgiem społecznym, z którego się wywodzili. Taka sytuacja niosła zaś dla tworzonej przez nich instytucji religijnej wiele korzyści, ale i zagrożeń. Wychodząc ze środowiska mieszczańskiego, które doceniało kult pracy i powodzenia w życiu doczesnym, ludzie ci potrafili znakomicie administrować klasztornym majątkiem oraz pomnażać i tak już wysokie dochody konwentu płynące $z$ różnego rodzaju stypendiów mszalnych, zapisów testamentowych, czynszów z miejskich nieruchomości i jatek, a także wielu okazjonalnych darowizn zasilających klasztorny skarbiec. Nie ulega jednak wątpliwości, że - z drugiej niejako strony - osoby te stanowiły zagrożenie dla pielegnowanych w zakonie ideałów ubóstwa, posłuszeństwa oraz czystości. To zderzenie korzyści i zagrożeń dla uświęconego tradycją modelu życia zakonnego dominikanów będzie najbardziej bodaj charakterystyczną cechą symbiozy, w jakiej wzrastały położone w obrębie miast klasztory, w tym także konwent w Poznaniu ${ }^{23}$.

Doceniając znaczenie powyższych ustaleń i traktując je jako fundament naszych własnych rozważań - raz jeszcze podejmujemy temat związany z działalnością poznańskich dominikanów. Od razu zastrzegamy przy tym, że nie jest oczywiście naszym zamiarem pisanie skróconej choćby monografii klasztoru. Interesuje nas wyłącznie zespół zamieszkujących go zakonników. Jesteśmy przekonani, że siegnięcie do wielu pomijanych dotąd źródeł pozwoli poszerzyć naszą wiedzę o tych ludziach.

\section{III}

Na sprowadzenie dominikanów do średniowiecznego grodu poznańskiego wywarła wielki wpływ ówczesna sytuacja polityczna, a także zaawansowanie w rozwoju gospodarczym dzielnicy. W literaturze zwrócono uwagę na względne - w porównaniu z innymi ziemiami - opóźnienie w fundacjach dominikańskich na terenie XIII-wiecznej Wielkopolski ${ }^{24}$. Istotnie, w granicach tej ziemi Bracia Kaznodzieje pojawili się o wiele później aniżeli w Małopolsce, na Śląsku, czy Pomorzu. Taki stan rzeczy da się dość łatwo wytłumaczyć długoletnim brakiem stabilizacji na terenie dzielnicy wielkopolskiej w I połowie XIII stulecia. Walki o panowanie nad Wielkopolską pomiędzy potomkami Mieszka Starego - Władysławem Laskonogim i Władysławem Odonicem - na pewno opóźniały sprowadzenie Braci Kaznodziejów do Poznania czy Gniezna ${ }^{25}$. Na późne wysłanie do tych grodów misji dominikańskiej z pewnością miała również wpływ słaba urbanizacja dzielnicy

${ }_{23} \mathrm{~J}$. W i e s i o ł o w s k i, Dominikanie w miastach wielkopolskich, passim.

${ }^{24}$ J. W i e s i o 1 o w s k i, Klasztory średniowiecznego Poznania, s. 406.

${ }^{25}$ Zob. G. L a b u d a, Dwaj rywale Whadystaw Laskonogi (1202-1231) i Wladystaw Odonic (1206-1239), w: Dzieje Wielkopolski, t. 1, pod red. J. Topolskiego, Poznań 1969, s. 288-293; M. P r z y b y 1, Wladysław Laskonogi, Poznań 1998. 
- wiadomo, że mendykanci osiadali w miastach lokowanych na prawie niemieckim i do tego silnych ekonomicznie, gdyż utrzymanie konwentu liczącego kilkunastu (lub więcej) zakonników wymagało od mieszczan sporego wysiłku finansowe$\mathrm{go}^{26}$. Biorąc pod uwagę te względy nie dziwi więc, że pierwsze klasztory dominikańskie na terenie Wielkopolski powstały długo po ich osadzeniu w Krakowie, Wrocławiu, czy Gdańsku.

W średniowiecznych źródłach spotykamy różne informacje na temat najdawniejszych dziejów klasztoru dominikanów w Poznaniu. Bernard Gui - dominikański inkwizytor i zarazem historyk zakonu kładł jego początki na lata 40-te XIV wieku. Jan Długosz natomiast podał w swoich „Rocznikach”, że poczatki klasztoru należy datować na rok 1231, kiedy to biskup Paweł miał sprowadzić zakonników na prawy brzeg Warty i osadzić ich przy kościele św. Małgorzaty na poznańskiej Śródce ${ }^{27}$. Trudno rozstrzygnąć, która z podanych wyżej możliwości wiernie oddaje początki interesującego nas konwentu. Za Bernardem Gui przemawia autorytet kompetentnego historyka własnego zakonu ${ }^{28}$, za Janem Długoszem - być może - dostęp do zaginionych dziś źródeł dominikańskich, w których mogły zachować się nieznane nam, ale wykorzystane przez kronikarza, informacje o najstarszych dziejach klasztoru w Poznaniu ${ }^{29}$. Różne opinie na temat założenia tego domu zakonnego jakie spotykamy w dawnych źródłach przeniosły się na poglądy współczesnej historiografii. Niektórzy autorzy uznają nieprzerwane istnienie dominikańskiego konwentu już od lat 30-tych XIII stulecia najpierw na Śródce, a później na lewym brzegu Warty ${ }^{30}$. Inni natomiast uznaja, że bracia przebywali co prawda od dawna w otoczeniu Władysława Odonica, ale ze względu na jego wojny z książętami śląskimi rezydowali oni początkowo przy kościele św. Krzyża w Gnieźnie i dopiero w latach 40-tych XIII wieku zostali oni osadzeni na terenie poznańskiej osady św. Gotarda. Ich pojawienie się w tym miejscu miało zaś być wstępem do przeniesienia Poznania na lewy brzeg Warty ${ }^{31}$.

Jak by nie było, faktem jest, że źródła dokumentowe poświadczają obecność dominikanów w Poznaniu dopiero w roku 1244 - książęta Przemysł I i Bolesław Pobożny przekazali wówczas braciom kościół św. Gotarda i pobliski teren pod budowę klasztoru ${ }^{32}$. Informacje o najstarszym zespole braci zamieszkujących nowo powstały dom zakonny są niestety bardzo nieliczne. Trudno nawet powie-

${ }^{26}$ A. S z u 1 c, Klasztory franciszkańskie w średniowiecznej Wielkopolsce. Kalisz, Gniezno, Śrem, Pyzdry, Oborniki, Poznań 2001, s. 15.

${ }^{27}$ J. A. S p i e ż, Dominikanie w Poznaniu, s. 6-8.

${ }^{28}$ P. K i e 1 a r, Bernard Guidonis OP, w: Encyklopedia Katolicka, t. 2, Lublin 1976, kol. 308-308.

${ }^{29}$ G. L a b u d a, Zaginiona kronika w Rocznikach Jana Dlugosza, Poznań 1983.

${ }^{30}$ J. A. S p i e ż, Dominikanie w Poznaniu, s. 7-8.

${ }^{31}$ J. W i e s i o 1 o w s k i, Klasztory średniowiecznego Poznania, s. 406.

${ }^{32}$ KDW, t. 1, Poznań 1877, s. 205-206 (nr 243). 
dzieć jak liczny był to konwent. Co prawda przepisy zakonne wymagały, aby zamieszkiwało go co najmniej 12 zakonników, ale zachowane źródła z XIII wieku nie pozwalają wprost odpowiedzieć na pytanie, czy warunek ten był przestrzegany w klasztorze poznańskim już w najstarszym okresie jego dziejów ${ }^{33}$. Tylko na podstawie pośredniego kryterium możemy domyślać się, że w II połowie XIII stulecia klasztor poznański nie miał większych problemów materialnych i personalnych. W roku 1264 odbyła się w jego murach kapituła polskiej prowincji dominikanów ${ }^{34}$ - klasztor musiał więc przyjąć na kilka dni delegatów pozostałych konwentów wchodzących w jej skład, zapewnić im utrzymanie i obsługę. Możemy więc domniemywać, że założony w latach 40 -tych tego wieku klasztor w ciagu następnych kilkunastu lat rozwijał się pomyślnie, a jego zamożność i stan osobowy wzrastały.

Jeśli chodzi o znane nam postaci zakonników poznańskich, to ze stulecia XIII zachowało się niewiele danych, na podstawie których możemy dziś wskazać konkretne osoby zamieszkujące klasztor w tych czasach. W roku $1243 \mathrm{w}$ otoczeniu księcia Przemysła I przebywali dwaj dominikanie: Jerzy oraz Piotr Hartung ${ }^{35}$, choć przy obecnym stanie wiedzy o początkach klasztoru w Poznaniu (por. wyżej) trudno rozstrzygnać, czy w roku wydania dokumentu, na którym postaci te występuja w roli świadków, konwent rezydował już w Poznaniu, czy też siedzibę dominikanów należy wówczas lokować tymczasowo w Gnieźnie. Z całą natomiast pewnością klasztor w osadzie św. Gotarda zamieszkiwal Piotr Hartung wraz ze swym towarzyszem - bratem Sulisławem - w roku $1249^{36}$. Kilka lat później (1254) wzmiankowany jest przeor poznański Mojżesz wraz z zakonnikiem Reimboldem (Reinoldem?) ${ }^{37}$. Najpełniejszy wykaz dominikanów poznańskich z tego okresu czasu przynosi dokument księcia Przemysła I z roku 1257, w którym wymieniono z imienia aż 7 zakonników - przeora Piotra, podprzeora Jakuba, lektora Witalisa, a także braci: Reinolda, Henryka, Lukasza oraz niejakiego Sedlika (Sedlicus) ${ }^{38}$. Zdaje się zreszta, że nie byli to wszyscy członkowie poznańskiego konwentu, gdyż dyplom wymienia także, choć już bez podawania konkretnych imion, innych zakonników z tego klasztoru (aliis fratribus de conventu). Grono znanych nam

${ }^{33} \mathrm{~J}$. W i e s i o ło w s k i, Dominikanie w miastach wielkopolskich, s. 243.

${ }^{34}$ Akta, s. 7.

${ }^{35} \mathrm{KDW}, \mathrm{t} .1$, s. 201-202 (nr 238). Nie jest shuszne wydzielenie spośród wzmiankowanych tam dominikanów trzech postaci: Jerzego, Piotra oraz Artunga (Hartunga), gdyż z innych dokumentów, na których występują postaci XIII-wiecznych dominikanów z Poznania, wynika dowodnie, że Atrung, bądź Hartung to przydomek brata Piotra (zob. niżej).

${ }^{36}$ KDW, t. 11, wyd. A. Gąsiorowski, T. Jasiński, T. Jurek i I. Skierska, Poznań 1999, s. 2-3 (nr 1704).

${ }^{37} \mathrm{KDW}$, t. 1 , s. 289-290 (nr 324).

${ }^{38}$ Ibidem, s. 313 (nr 352). Brat Piotr byl przeorem klasztoru poznańskiego co najmniej do roku 1259 - zob. tamże, s. 334 (nr 377); K o r o l e c I, s. 209 (nr 29); B u c i c h o w s k i, s. $210(\mathrm{nr} 1040)$. 
dominikanów poznańskich z XIII wieku uzupełnia jeszcze brat Teodoryk, lektor konwentu i spowiednik księcia Przemysła II, wzmiankowany w latach 1279$1283^{39}$. Możliwe (choć całkowitej pewności w tym względzie nie mamy), że klasztor poznański zamieszkiwał również Paweł Polak (Paulus Polonus), którego papież Innocenty IV przeniósł w roku 1250 na biskupstwo poznańskie ${ }^{40}$. Późna tradycja dominikańska przypisuje mu wieloletnie pełnienie przed tą nominacją funkcji inkwizytora, choć nie oznacza dokładnie terenu podlegającego jego władzy ${ }^{41}$. Lista znanych nam z imienia dominikanów poznańskich z XIII wieku jest więc bardzo krótka i obejmuje raptem kilkanaście postaci. Jest to stanowczo zbyt mała grupa, aby na podstawie jej składu wyciagnąć jakieś pewne wnioski co do liczebności, pochodzenia, składu społecznego i wykształcenia zakonników czy ich rodzinnych powiązań. Co charakterystyczne i poniekąd zrozumiałe, blisko połowa zachowanych informacji dotyczy osób funkcyjnych - przeorów, podprzeorów czy też inkwizytorów, którzy z racji pełnionych urzędów mieli o wiele większe szanse na odnotowanie swych imion w źródłach od zwykłych, szeregowych rzec można, zakonników.

Tabela 1. Zakonnicy klasztoru dominikanów w Poznaniu w XIII wieku

\begin{tabular}{l|l|l|l|l}
\hline \multicolumn{1}{c|}{ Przeorowie } & Podprzeorowie & \multicolumn{1}{|c|}{ Lektorzy } & Inkwizytorzy & \multicolumn{1}{c}{ Bracia } \\
\hline 1. Mojżesz & 1. Jakub & 1. Witalis & 1. Pawel Polak? & 1. Jerzy? \\
2. Piotr & & 2. Teodoryk & & 2. Piotr Hartung \\
& & & & 3. Sulisław \\
& & & 4. Reimbold? \\
& & & & 5. Reinold \\
& & & & 6. Henryk \\
& & & & 7. Lukasz \\
& & & & 8. Sedlilk \\
\hline
\end{tabular}

Równie mało wiadomości o poznańskich dominikanach przynosząźródła XIV-wieczne. Podstawa dokumentowa do dziejów klasztoru w tym stuleciu jest niestety bardzo skromna i tylko zapisom samych dominikanów (fragmenty akt kapitul prowincji polskiej, Zbiór formul) zawdzięczamy nieco informacji o ówczesnym konwencie poznańskim.

\footnotetext{
${ }^{39} \mathrm{KDW}, \mathrm{t} .1$, s. $457-458$ (nr 489) i s. $485-486$ (nr 520), K o r o 1 e c I, s. 210 (nr 30); B u c i c how s ki, s. 203 (nr 981).

${ }^{40}$ A. B z ow s k i, Propago D. Hyacinthi thaumaturgi Poloni seu de rebus praecalare gestis in Prouincia Poloniae Ordnis Praedicatorum, Venetiis 1606, s. 50 (cyt. dalej: B z o w s k i).

${ }^{41} \mathrm{~T}$ e 1 e ży ń ski, fol. 58r. Wedhug tego samego autora (fol. 6v) przed objęciem funkcji biskupiej Paweł miał sprawować funkcję penitencjarza papieskiego: F. Paulus post Ep [iscopus] Pozn[aniensis]. Zakonnik ten nie jest bez wątpienia identyczny z biskupem Pawlem, który w roku - być może - 1231 osadził dominikanów na poznańskiej Śródce - zob. B u c i c h o w s k i, s. 183 (nr 817). Co do tej ostatniej postaci, to brak jakichkolwiek przesłanek aby w ogóle uznać ją za należącą do Zakonu Kaznodziejskiego.
} 
Najczęściej bodaj wzmiankowaną postacią z początku tego stulecia jest brat Dominik, na przemian lektor i przeor konwentu w latach 1302-1307, a nastepnie (od roku 1310 aż do śmierci około roku 1323) sufragan metropolity gnieźnieńskiego i biskup tytularny meteleński ${ }^{42}$. Z innych przełożonych konwentu w XIV wieku znamy Franciszka, kierującego klasztorem w roku $1321^{43}$, a także brata Jana, lektora poznańskiego, który w roku 1373 został przez władze zakonu wyniesiony na stanowisko przeora ${ }^{44}$.

Nieco wiadomości o zakonnikach poznańskich przynoszą także zachowane do naszych czasów fragmenty ustaw kapituł polskiej prowincji dominikanów z lat 30 i 70-tych. Informują one o skierowanych do Poznania studentach, którzy mieli wykładać i pobierać nauki w miejscowym studium partykularnym. W pierwszej połowie XIV wieku miał w nim nauczać jakiś brat $P$ (Paulus?, Petrus? $)^{45}$. Znamy także imiona kilku zakonników, których władze prowincji skierowały na studia do Poznania. W latach 30-tych tego stulecia przybyli tam po naukę: Pribikonus z Wrocławia, Teodoryk z Płocka, Wacław oraz Mikołaj ${ }^{46}$. W latach 70 -tych zaś zjawili się tam: Mikołaj Kluka, Piotr z Torunia, a także brat Walter z klasztoru w Erfurcie ${ }^{47}$. Do wymienionych wyżej należy dodać jeszcze penitancjarza papieża Grzegorza XI - magistra Pawła z Poznania ${ }^{48}$, a także wzmiankowanych przez Zbiór formut poznańskich zakonników: Stefana $(1373)^{49}$ oraz Jana Pałukę $(1374)^{50}$.

Fragment ustawy kapituły prowincji polskiej z drugiej połowy XIV wieku wymienia również jakiegoś Mikołaja z Poznania (Nicolaum Poznanensem), zakonnika klasztoru dominikanów w Oświęcimiu, skierowanego na naukę do śląskich Ząbkowic ${ }^{51}$. Enigmatyczność zapisu nie pozwala rozstrzygnąć czy chodzi tu o Mikołaja urodzonego w Poznaniu, który od początku związał swoje życie zakonne z klasztorem oświęcimskim, czy też ustawa mówi o jednym z zakonników poznańskich przeniesionych najpierw do Oświęcimia, a następnie wysłanego na stu-

${ }^{42} \mathrm{KDW}$, t. 2, Poznań 1878, s. 208-209 (nr 852), 235 (nr 884), 250 (nr 902) i 255 (nr 908); K o r o 1 e c I, s. 210 (nr 31); B u c i c how s k i, s. 95 (nr 155). Por. P. C z a p l e w s k i, Tytularny episkopat w Polsce średniowiecznej, „Roczniki Towarzystwa Przyjaciół Nauk Poznańskiego", 40 (1914), s. 133-136.

${ }^{43}$ Lites ac res gestae inter Polonos Ordinemque Cruciferorum, wyd. H. Chłopocka, Wroclaw - Warszawa - Kraków 1970, s. 75.

${ }_{44}$ Zbf, s. 303 (nr 114) i 305 (nr 118); K o r o 1 e c I, s. 210 (nr 32); B u c i c h o w s k i. s. 124 (nr 379).

${ }^{45} \mathrm{~K}$ i e 1 a r, s. 314.

${ }^{46}$ Ibidem.

${ }^{47}$ Ibidem, s. 315.

${ }^{48} \mathrm{~B}$ z ow s k i, s. 87 i T e 1 e ż y ń s k i, fol. $109 \mathrm{v} \mathrm{z}$ podaniem daty $1376 \mathrm{r}$.

${ }^{49}$ Zbf, s. 305 (nr 118).

${ }^{50}$ Ibidem, s. 260 (nr 6).

${ }^{51} \mathrm{~K}$ i e 1 a r, s. 315. 
Tabela 2. Zakonnicy klasztoru dominikanów w Poznaniu w XIV wieku*.

\begin{tabular}{l|l|l|l|l|l}
\hline Przeorowie & Lektorzy & Inkwizytorzy & $\begin{array}{c}\text { Wykladowcy } \\
\text { w szkole } \\
\text { partykularnej }\end{array}$ & $\begin{array}{c}\text { Studenci } \\
\text { szkoly } \\
\text { partykularnej }\end{array}$ & \multicolumn{1}{c}{ Bracia } \\
\hline $\begin{array}{l}\text { 1. Dominik } \\
\text { 1. Dominik }\end{array}$ & 1. Chryzostom? & $\begin{array}{l}\text { 1. P(Pawel?, } \\
\text { Piotr?) }\end{array}$ & $\begin{array}{l}\text { 1. Pribiconus } \\
\text { 3. Franciszek }\end{array}$ & $\begin{array}{l}\text { 2. Teodoryk } \\
\text { 3. Waclaw } \\
\text { 4. Mikolaj } \\
\text { 5. Mikolaj Kluka } \\
\text { 6. Piotr Homianda } \\
\text { 7. Walter }\end{array}$ & $\begin{array}{l}\text { 1. Stefan } \\
\text { 2. Wincenty? } \\
\text { 3. Mikołaj? } \\
\text { 4. Mag. Pawel }\end{array}$ \\
\hline
\end{tabular}

* Pogrubiona czcionka zaznaczono postaci sprawujące na przemian funkcje lektora i przeora, po to, by wyraźnie zaznaczyć, że chodzi o te same osoby

dia na Ślask. Późne źródła dominikańskie podają dodatkowo dwa inne imiona dominikanów, którzy - być może - w XIV wieku zamieszkiwali klasztor poznański: Chryzostoma (albo Jana Chryzostomi), który w pierwszej połowie tego stulecia miał zostać inkwizytorem per Maiorem Polonias ${ }^{52}$, a także doktora teologii Wincentego, który w roku 1326 został sufraganem biskupa poznańskiego Jana III ${ }^{53}$. Nasza wątpliwość co do przyporządkowania ich do tego konwentu bierze się stąd, że źródła nie podają aby zakonnicy ci przebywali w klasztorze poznańskim, tylko przypisują im pełnienie określonych funkcji na terenie Wielkopolski. Zważywszy na znana powszechnie mobilność dominikanów i ich częste wędrówki pomiędzy różnymi klasztorami jest w tej sytuacji możliwe, że przed przeniesieniem ich na urzędy związane z tą dzielnicą zamieszkiwali jakiś klasztor poza jej granicami. Równie (a może nawet bardziej) prawdopodobne jest jednak, że obaj ci zakonnicy

${ }^{52} \mathrm{~W}$ odniesieniu do tej postaci wątpliwości budzi samo jej imię, a także czas pełnienia przez zakonnika funkcji inkwizytorskiej. B z o w s k i (s. 69) informuje, że inkwizytorem wielkopolskim w roku 1348 byl Joannes Chrisostomus (Chrisostomi? - K. K.), T e 1 e ż y ń s k i zaś twierdzi (fol. 93v), że funkcję tą miał w roku 1327 pelnić niejaki Chryzostom. Tej różnicy zdań rozstrzygnąć nie sposób, ponieważ jest to postać nieznana współczesnym, średniowiecznym, źródłom.

${ }^{53}$ Ibidem, fol. 3v i 92r. T e l e ż y h́ s $\mathrm{k}$ i podaje co prawda, że brat Wincenty został wyniesiony do godności biskupiej, ale aż tak wielki awans nie wydaje się możliwy ze względu na znana nam chronologię rządów biskupa Jana III (1324-1335). Stąd ks. Józef Nowacki podejrzewał, że zakonnik został nie tyle rządcą diecezji, co sufraganem jej ordynariusza. Zdaniem tego autora, w przypadku Wincentego możliwa byla także zwyczajna pomyłka, polegająca na pomyleniu go ze znaną powszechnie postacią Wincentego Wierzbięty, również dominikanina, sufragana poznańskiego z II połowy XV wieku - zob. J. N o w a c k i, Dzieje Archidiecezji Poznańskiej, t. 2, Poznań 1964, s. 178. 
byli związani w klasztorem poznańskim i jako osobom z pewnością wykształconym oraz znającym teren biskupiej i inkwizytorskiej misji powierzono im te eksponowane funkcje. $Z$ tego powodu (choć ze znakami zapytania) uwzględniamy ich w naszym zestawieniu członków tego konwentu w XIV wieku.

Podobnie jak w wieku XIII również zestawienie zakonników poznańskich z następnego stulecia obejmuje zaledwie kilkanaście osób, w większości studentów szkoły partykularnej, która jak widać w tych czasach działała w murach tego klasztoru. Pokazuje ono także (na razie w niewielkim jeszcze stopniu) jak wielka była wśród dominikanów wymiana kadr pomiędzy poszczególnymi domami zakonnymi. Pribikonus przybył na studia w klasztorze poznańskim z Wrocławia, brat Teodoryk z Płocka, Piotr z Torunia a Walter aż z Erfurtu. Nie wiemy niestety jak długo wymienione osoby pozostawały w klasztorze w Poznaniu. Możliwe, że ich pobyt trwał tylko kilka lat - tak długo, jak wymagał tego program prowadzonych przez zakonników studiów. Nie jest jednak wykluczone (choć nie da się tego udowodnić z powodu milczenia źródeł), że niektórzy z nich na mocy decyzji władz prowincji swoje zakonne życie związali z klasztorem poznańskim na wiele lat.

Najpełniejsze informacje o składzie konwentu dominikanów z Poznania pochodzą z wieku XV. Fakt ten zawdzięczamy bez watpienia istnieniu najszerszej i najbardziej zróżnicowanej dla tego właśnie stulecia podstawy źródłowej (dokumenty klasztorne opublikowane w kodeksach dyplomatycznych, kopiarze zawierające sporą liczbę dyplomów nie wydanych dotąd drukiem, akta kapituł polskiej prowincji dominikanów, a także akta poznańskiej kapituły katedralnej). Materiały te dobrze oświetlają skład konwentu, z zastrzeżeniem jednak, że nie obejmują one ostatniej ćwierci tego stulecia. Akta kapituł dla tego okresu po prostu w ogóle się nie zachowały; brakuje też z pewnością wielu dokumentów i akt zakonnych z samego Poznania - tamtejszy klasztor spalił się w roku 1464 i wiele archiwaliów w czasie tej klęski zapewne bezpowrotnie przepadło ${ }^{54}$.

To jednak co przetrwało do naszych czasów pozwala nam zestawić obszerną listę XV-wiecznych przeorów klasztoru poznańskiego. Wiemy, że w latach 1403-1404 funkcję tę pelnił brat Tadeusz ${ }^{55}$. Następnie, około roku 1410, urząd ten piastował Mikołaj ${ }^{56}$, w roku 1413 ponownie Tadeusz ${ }^{57}$, a później Stefan $(1420-1422)^{58}$,

\footnotetext{
${ }^{54} \mathrm{~J}$. W i e s i o 1 o w s k i, Dominikanie w miastach, s. 218.

${ }^{55}$ KDW, t. 7, wyd. A. Gąsiorowski, R. Walczak, Warszawa - Poznań 1985, s. 176-177 (nr 483); 276-277 (nr 530).

${ }^{56} \mathrm{Zbf}, \mathrm{s.} 302-303$ (nr 112).

${ }^{57} \mathrm{KDW}$, t. 7 , s. $518-520$ (nr 717).

${ }^{58}$ Ibidem, t. 8, wyd. A. Gąsiorowski i T. Jasiński, Warszawa - Poznań 1989, s. 167-172 (nr 899); t. 11, wyd. A. Gąsiorowski, T. Jasiński, T. Jurek, I. Skierska, Poznań 1999, s. 203-204
} (nr 1937). 
Mikołaj (ok. 1427) ${ }^{59}$, Dobiesław (1436) ${ }^{60}$ i Piotr Kuba ${ }^{61}$. W latach 50-tych klasztorem poznańskim kierowali kolejno: Jakub $(1452)^{62}$, Marcin $(1453)^{63}$, Pawel $(1456)^{64}$ oraz Mikołaj Doleatoris $(1458)^{65}$. W latach 60 -tych przeorami u dominikanów w Poznaniu byli: Wincenty Wierzbięta $(1461)^{66}$, Marcin Knolla $(1461)^{67}$, Jakub (1462) $)^{68}$, a następnie ponownie Wincenty Wierzbięta $(1464-1468)^{69}$. W latach 70-tych konwentowi przewodzili Mikołaj $(1471)^{70}$ oraz Jan $(1477)^{71}$. Przeorów z końca XV wieku znamy już o wiele gorzej - wiadomo, że w latach 14831485 urząd ten sprawował brat Mikołaj ${ }^{72}$, a w roku 1495 na stanowisku tym odnajdujemy jakiegoś Mikołaja syna Jerzego (Nicolaus Georgii) ${ }^{73}$. Ponieważ źródło podaje, że był on multis annis prior Posnanensis i dodatkowo jeszcze pełnił funkcję wikariusza kontraty wielkopolskiej, możemy domyślać się, że wzmianki o przeorze Mikołaju z lat 1483-1495 dotyczą jednej i tej samej osoby.

Z innych urzędników klasztornych w XV wieku znamy jeszcze: podprzeora Ambrożego (1471) ${ }^{74}$, zakrystianów: Marcina z Głogowa (1413) ${ }^{75}$ i Grzegorza $(1446)^{76}$, prokuratora konwentu z roku 1413 brata Mikołaja Nigri ${ }^{77}$, a także organistę - brata Piotra $(1461)^{78}$. Dość liczne grono dominikańskich oficjalów z Poznania stanowili także lektorzy konwentu oraz wykładowcy działających w Poznaniu szkół partykularnych. Ich poczet w XV wieku otwiera brat Paweł, wzmiankowany na tym urzędzie w październiku 1404 roku $^{79}$. Pod rokiem 1407 odnajduje-

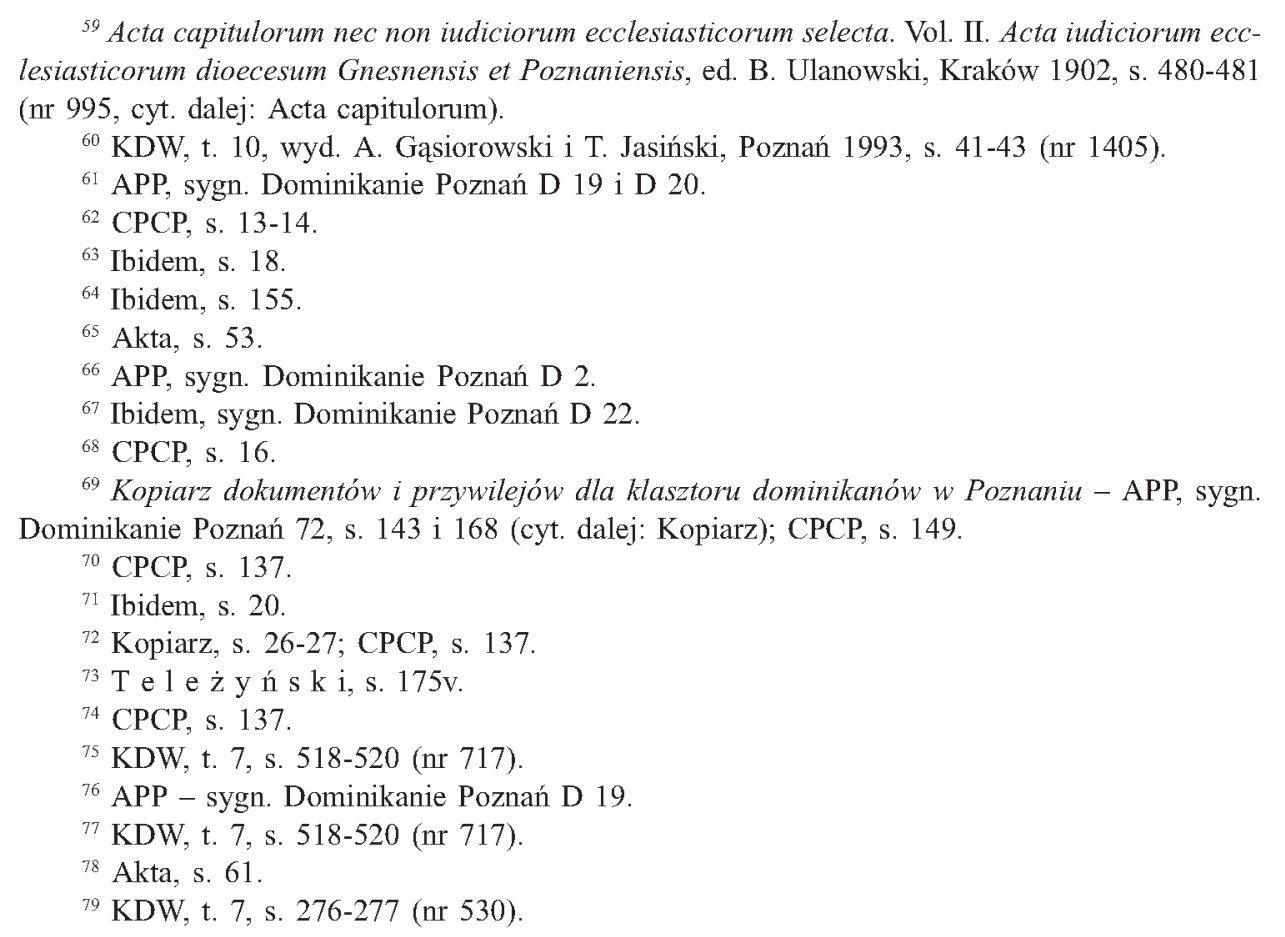


my jakiegoś brata Jana, magistra studentów de s. Domenico z Poznania ${ }^{80}$. Od roku 1458 funkcję lektora konwentu pełnili jednocześnie Piotr oraz Wincenty Lubarski ${ }^{81}$, w roku 1461 ponownie Wincenty Lubarski oraz Marcin Knolle ${ }^{82}$, a rok później na urzędzie tym akta zakonne wzmiankują Marcina z przydomkiem Hnona ${ }^{83}$ (czyżby chodziło o tę samą osobę - Knolle/Hnona?). W roku 1458 władze prowincji mianowały Stanisława Salsa bakałarzem w konwencie poznańskim ${ }^{84}$; bakałarzem partykularnej szkoły teologii był zapewne również kursor poznański Mikołaj Visunis, wysłany w roku 1461 na studia do Tuluzy ${ }^{85}$. Z roku 1462 znamy brata Mikołaja Kolera - ówczesnego lektora gramatyki ${ }^{86}$, a z 1463 Mikołaja Weyschenczila - lektora $s z t u k^{87}$. Ważną postacią w każdym konwencie dominikańskim był kaznodzieja (lub kaznodzieje, w wypadku, gdy zróżnicowane narodowościowo środowisko wymagało głoszenia kazań także w języku obcym). Jeśli chodzi o konwent poznański, to z XV wieku znamy kaznodzieję dla Polaków Jana z Dolska, wymienionego w aktach kapituły prowincji polskiej z roku 1458 zebranej właśnie w klasztorze w Poznaniu ${ }^{88}$, wzmiankowanego pod tym samym rokiem kaznodzieję niemieckiego lektora Piotra z Poznania (zob. wyżej), a także pełniących tą samą funkcje kilka lat później: Marka Kreczmera (1461) ${ }^{89}$ i Mikołaja Kolera (1462 - zob. wyżej). Potrafimy też wymienić jednego z piętnastowiecznych inkwizytorów wielkopolskich rezydujących w Poznaniu - w latach dwudziestych funkcję tą pełnił urzędujący wówczas przeor konwentu, brat Mikołaj90.

Potrafimy także wskazać całkiem liczne grono szeregowych rzec można zakonników zamieszkujących konwent dominikanów poznańskich w XV wieku. W roku 1413 przebywali w klasztorze bracia: Michał, Andrzej z Opola, Maciej Piscatoris, Stefan z Łęczycy (czyżby późniejszy przeor Stefan? - zob. wyżej), Klemens, Szymon Nigri, Mikołaj z Opola oraz Michał Szekuka ${ }^{91}$. W roku 1420 zakonnikiem w tym konwencie byli Tomasz Lowiszek ${ }^{92}$ oraz Piotr Welislawynne ${ }^{93}$,

${ }^{80}$ J. N o w a c k i, Dzieje Archidiecezji, t. 2, s. 672.

${ }^{81}$ Akta, s. 49.

${ }^{82}$ Ibidem, s. 61.

${ }^{83}$ Ibidem, s. 73

${ }^{84}$ Ibidem, s. 49.

${ }^{85}$ Ibidem, s. 63.

${ }^{86}$ Ibidem, s. 70.

${ }^{87}$ Katalog rękopisów Biblioteki Katedralnej w Gnieźnie. Rękopisy Zespolu Seminaryjnego. oprac. J. Ryl, „Archiwa, Biblioteki i Muzea Kościelne”, 46 (1983), s. 7 (nr 1004).

${ }^{88}$ Ibidem, s. 49.

${ }^{89}$ Ibidem, s. 61

${ }^{90}$ Acta capitulorum, s. 480-481 (nr 995).

${ }^{91} \mathrm{KDW}$, t. 7 , s. $518-520$ (nr 717).

${ }_{92}$ J. W i e s i o 1 o w s k i, Dominikanie w miastach, s. 243 na podstawie akt kapituly katedralnej z Poznania.

${ }_{93}$ Stadtbuch von Posen. Acten des städtischen Rathes 1398-1433, ed. A. Warschauer, Posen 1892 , s. 118 (nr 343). 
w $1421 \mathrm{Jan}^{94}$, a w 1444 Mikołaj Koler ${ }^{95}$ - wszyscy z Poznania. W roku 1447 z Poznania wyjechali: brat Henryk, którego władze prowincji skierowały na studia do Ząbkowic ${ }^{96}$, a także Wincenty mianowany lektorem konwentualnym w Krako$w^{2} e^{97}$. Pod tą samą datą wzmiankowany jest w aktach kapituł jakiś Mikołaj z Poznania, przeor w Środzie ${ }^{98}$, a także kilku braci, których władze prowincji przeniosły wówczas do klasztoru poznańskiego: Lukasz z Sandomierza, Wawrzyniec Ciceler oraz Wacław ${ }^{99}$, a także nieznany bliżej magister Maciej z Poznania ${ }^{100}$. Akta konsystorza poznańskiego wzmiankują pod rokiem 1452 jakiegoś brata Macieja od św. Dominika ${ }^{101}$. W roku 1458 władze prowincji skierowały do Poznania brata Jana Pellificis ${ }^{102}$. Kilka lat później (1461) w aktach kapituły prowincjalnej zebranej w klasztorze w Lęczycy wzmiankowani sa: przeniesieni do Poznania z różnych konwentów Mikołaj Kummer, Marcin Hrobronik, Jan Cautoris i Mikołaj Concerdorf ${ }^{103}$, przysłani na studia: Mikołaj Clementis i Mikołaj z Kalisza ${ }^{104}$, a także Ambroży Fligel, zakonnik z Poznania, którego władze prowincji przeniosły do Wrocławia ${ }^{105}$. W latach 60 -tych klasztor poznański zamieszkiwali również: Mikołaj (1462) ${ }^{106}$, Michał Kopeć (1463) $)^{107}$ Michał Zilicki (1463) ${ }^{108}$, Stanisław Gladiatoris $(1465)^{109}$, Wojciech Puchała $(1466)^{110}$, Mikołaj Konik $(1467)^{111}$, Maciej ze Środy $(1468)^{112}$ oraz Stanisław $(1468)^{113}$. W latach 70 -tych w konwencie przebywali: Jan (1471) $)^{114}$ oraz Andrzej Statek (1474) $)^{115}$. Z samego końca XV wieku mamy

${ }^{94}$ Ibidem, s. 123-124 (nr 356).

${ }^{95} \mathrm{~J}$. W i e s i o $\nmid$ o w s k i, Dominikanie w miastach, s. 243.

${ }^{96}$ Akta, s. 29.

${ }^{97}$ Ibidem, s. 31.

${ }^{98}$ Ibidem, s. 30.

${ }^{99}$ Ibidem, s. 29.

${ }^{100}$ Acta capitulorum, s. 560 (nr 1226).

${ }^{101}$ Acta causamim consistorii posnaniensis 33, fol. 187 V (cytuję za Kartoteka Slownika Historyczno-Geograficznego Województwa Poznańskiego w zbiorach Instytutu Historii PAN w Poznaniu)

${ }^{102}$ Akta, s. 49.

${ }^{103}$ Ibidem, s. 61.

${ }^{104}$ Ibidem.

${ }^{105}$ Ibidem, s. 60.

${ }^{106} \mathrm{~J}$. W i e s i o ł o w s k i, Dominikanie w miastach, s. 243. Być może zakonnik ten jest identyczny ze wzmiankowanym $\mathrm{w}$ aktach kapituly prowincji polskiej zebranej w roku 1463 w Glogowie bratem Mikołajem G[...] - zob. Akta, s. 70.

${ }^{107} \mathrm{~J}$. W i e s i o ł o w s k i, Dominikanie w miastach, s. 243.

${ }^{108}$ Ibidem, s. 244

${ }^{109}$ Akta, s. 82

${ }^{110} \mathrm{~J}$. W i e s i o ł o w s k i, Dominikanie w miastach, s. 244.

${ }^{111}$ Ibidem.

${ }_{112}^{112}$ Akta, s. 92.

113 Ibidem, s. 95.

${ }^{114}$ J. W i e s i o 1 o w s k i, Dominikanie w miastach, s. 244.

i1s Ibidem. 
Tabela 3. Zakonnicy klasztoru dominikanów w Poznaniu w XV wieku*

\begin{tabular}{|c|c|c|c|c|c|c|c|c|}
\hline Przeorowie** & $\begin{array}{c}\text { Pod- } \\
\text { przeorowie }\end{array}$ & $\begin{array}{l}\text { Lektorzy i } \\
\text { Bakałarze }\end{array}$ & Kaznodzieje & Inkwizytorzy & Prokuratorzy & Zakrystianie & Organiści & Bracia \\
\hline $\begin{array}{l}\text { 1. Tadeusz } \\
\text { 2. Mikołaj } \\
\text { 3. Stefan } \\
\text { 4. Mikolaj } \\
\text { 5. Dobiesław } \\
\text { 6. Piotr Kuba } \\
\text { 7. Jakub } \\
\text { 8. Marcin } \\
\text { 9. Paweł } \\
\text { 10. Mikołaj } \\
\text { Doleatoris } \\
\text { 11. Wincenty } \\
\text { Wierzbięta } \\
\text { 12. Marcin } \\
\text { Knolla } \\
\text { 13. Jakub } \\
\text { 14. Mikołaj } \\
\text { 15. Jan }\end{array}$ & 1.Ambroży & $\begin{array}{l}\text { 1. Paweł } \\
\text { 2. Jan } \\
\text { 3. Piotr z } \\
\text { Poznania } \\
\text { 4. Wincenty } \\
\text { Lubarkki } \\
\text { 5. Marcin Knolle } \\
\text { 6. Marcin Hnona } \\
\text { 7. Stanisław Salsa } \\
\text { 8. Mikołaj Visunis } \\
\text { 9. Mikolaj Koler } \\
\text { 10. Mikołaj } \\
\text { Weyschenzel }\end{array}$ & $\begin{array}{l}\text { 1. Jan z Dolska } \\
\text { 2. Piotr z } \\
\text { Poznania } \\
\text { 3. Marek } \\
\text { Kreczmer } \\
\text { 4. Mikolaj } \\
\text { Koler }\end{array}$ & 1. Mikolaj & $\begin{array}{c}\text { 1. Mikołaj } \\
\text { Nigri }\end{array}$ & $\begin{array}{l}\text { 1. Marcin } \\
\text { 2. Grzegorz }\end{array}$ & 1. Piotr & $\begin{array}{l}\text { 1. Michał } \\
\text { 2. Andrzej z Opola } \\
\text { 3. Maciej Piscatoris } \\
\text { 4. Stefan z Łęczycy } \\
\text { 5. Klemens } \\
\text { 6. Szymon Nigri } \\
\text { 7. Mikołaj z Opola } \\
\text { 8. Michał Szekuka } \\
\text { 9. Tomasz Łowiszek } \\
\text { 10. Piotr Welislawynne } \\
\text { 11. Jan } \\
\text { 11. Henryk } \\
\text { 12. Wincenty } \\
\text { 13. Mikołaj } \\
\text { 14. Łukasz z Sandomierza } \\
\text { 15. Wawrzyniec Ciceler } \\
\text { 16. Wacław } \\
\text { 17. Mgr Maciej } \\
\text { 18. Jan Pellificis } \\
\text { 19. Maciej } \\
\text { 20. Mikołaj Kummer } \\
\text { 21.Marcin Hrobronik } \\
\text { 22. Jan Cautoris } \\
\text { 23. Mikołaj Concerdorf } \\
\text { 24. Mikołaj Clementis } \\
\text { 25. Mikołaj z Kalisza } \\
\text { 26. Ambroziy } \\
\text { 27. Mikołaj } \\
\text { 28. Michał Kopeć } \\
\text { 29. Michał Zilicki } \\
\text { 30. Stanisław Gladiatoris } \\
\text { 31. Wojciech Puchała } \\
\text { 32. Mikołaj Konik } \\
\text { 33. Maciej ze Srody } \\
\text { 34. Stanisław } \\
\text { 35. Jan } \\
\text { 36. Andrzej Statek } \\
\text { 37. Andrzej } \\
\text { 38. Michał Jacobi } \\
\text { 39. Maciej z Rostocku }\end{array}$ \\
\hline
\end{tabular}

* Podobnie jak w tabeli nr 2 także w powyższym zestawieniu pogrubioną czcionka wyróżniono osoby sprawujące różne urzędy klasztorne.

** Niektóre z wymienionych osób (Tadeusz, Wincenty Wierzbięta, Mikołaj) sprawowaly urzedy przeorów poznańskich po kilka razy, czego w samej tabeli nie uwzględniamy. 
bardzo mało informacji o poznańskich dominikanach. Około roku 1483 brat Andrzej wyjechał na studia do Bolonii ${ }^{116}$, dwa lata później (1485) akta zakonne wzmiankują brata Michała Jacobii ${ }^{117}$, a w roku 1491 władze prowincji przeniosły do Wielkopolski Macieja z Rostocku ${ }^{118}$.

Z przebadanych wyżej trzech stuleci funkcjonowania klasztoru dominikanów w Poznaniu (XIII-XV w.) znamy więc imiona około 100 zakonników tworzących miejscowy zespół braci. Udało się ustalić 14 imion braci z wieku XIII, 18 ze stulecia XIV i aż $72 \mathrm{z}$ wieku XV. Tak duże dysproporcje są bez wątpienia efektem bardzo zróżnicowanej dla średniowiecznego okresu dziejów klasztoru podstawy źródłowej. Przypomnijmy - dla dwóch pierwszych stuleci jego istnienia dysponujemy bardzo ograniczona podstawą dokumentową i zachowanymi w śladowych wręcz ilościach sprawozdaniami z obrad kapituł polskiej prowincji zakonu. Uboga w te przekazy jest także sama końcówka wieku XV - akt kapituł z tego czasu także nie ma, niewiele również zachowało się źródeł dokumentowych, co jest zapewne efektem pożaru zabudowań klasztomych $\mathrm{z}$ lat 60-tych tego stulecia. Podając do wiadomości przytoczone wyżej liczby trzeba więc mieć świadomość tego, że są one silnie zdeterminowane ilością i charakterem dostępnych analizie materiałów źródłowych.

Odtworzone postaci dominikanów poznańskich, zwłaszcza z wieku XV, pokazują też, że zamieszkiwany przez nich konwent był środowiskiem bardzo mobilnym, a jego skład ulegał częstym zmianom. O takim charakterze zespołu braci decydowały w największym stopniu dwa czynniki: sam sposób życia mendykantów, wymagający częstego przemieszczania się zakonników (kwesta, studia, kaznodziejstwo), a także polityka kadrowa władz zakonu, która polegała na częstym przenoszeniu braci do różnych klasztorów w obrębie prowincji a nawet poza nią.

Pochodzenie społeczne zakonników dominikańskich z Poznania było przedmiotem wnikliwych badań J. Wiesiołowskiego. Ustalił on, że zagadnienie to jest praktycznie nieuchwytne źródłowo aż do wieku XV. Autor ten stwierdził także, że u schyłku wieków średnich większość zakonników reprezentowała stan mieszczański, w tym zwłaszcza ta jego część, która miała bardzo bliski, rzec można fizyczny kontakt z klasztorem i zamieszkiwała jego najbliższe okolice. Bardzo skromny natomiast był napływ w szeregi konwentu dominikańskiego wielkopolskiej szlachty ${ }^{119}$. Nie ujmując niczego z tych wniosków, podkreślamy jednak, że skład konwentu dominikańskiego tylko do pewnego stopnia zależał od postawy jego sąsiadów, stanowiących bez wątpienia podstawowe zaplecze społeczne,

116 Akta, s. 115

${ }^{117}$ Magistrorum ac procuratorum generalium O. P. registra litterarum minora (1469-1523), wyd. G. Meersseman i D. Planzer, Romae 1957, s. 51 (nr 85).

118 Akta, s. 119.

${ }^{119} \mathrm{~J}$. W i e s i o 1 o w s k i, Dominikanie $w$ miastach, s. 242-248. 
z którego rekrutowały się nowe powołania. Do klasztoru napływali przecież (i to w całkiem dużej liczbie) ludzie spoza Poznania, a nawet spoza Wielkopolski, kierowani tam przez władze polskiej prowincji zakonu. Przyjmując więc do wiadomości wnioski o mieszczańskim charakterze konwentu, zwracamy jednak uwage, iż teza ta wymaga sprawdzenia i zweryfikowania także w odniesieniu do osób przeniesionych do klasztoru z zewnątrz.

Życie wewnętrzne konwentu znamy słabo. Nie ulega wątpliwości, że mieszczańskie w większości pochodzenie zakonników w znaczny sposób determinowato ich zachowania. Silne związki rodzinne i majątkowe łączące ich z mieszkającymi opodal klasztoru krewnymi i określony system wartości wpojony im jeszcze przed wstapieniem do zakonu musiały silnie oddziaływać na życie braci. Stąd najprawdopodobniej brała się wielka troska zakonników o materialną pomyślność konwentu. Ofiarność donatorów, ale i duże umiejętności braci w pomnażaniu darowanego im majątku sprawiły, że w XV wieku klasztor dominikanów poznańskich dysponował sporymi nadwyżkami kapitału i umiejętnie lokował je na miejskich nieruchomościach i dobrach ziemskich poza granicami Poznania ${ }^{120}$. Taka sytuacja (sprzeczna przecież z mendykanckimi ideałami) musiała prowadzić do pewnego rozprężenia obyczajów i karności zakonnej. Skala tego zjawiska jest jednak trudna do precyzyjnego uchwycenia. Dominikanie poznańscy bardzo rzadko byli obiektem sądów zakonnych, a ich imiona praktycznie nie pojawiają się w wykazach ukaranych braci, które zamieszczano w sprawozdaniach z posiedzeń kapituł polskiej prowincji zakonu. Tylko raz - w roku 1468 - kapituła zebrana w klasztorze w Warce skazała brata Stanisława z Poznania na rok karceru za włóczęgostwo i niemoralne prowadzenie się $e^{121}$. Można jednak watpić czy takie zachowania były w przypadku dominikanów poznańskich regułą. O jakimś zamieszaniu w konwencie w latach 80-tych XV wieku, którego istoty nie sposób jednak dociec, może również świadczyć sprawa brata Michała Jacobi. W roku 1485 władze zakonu zadecydowały o jego przeniesieniu in quocumque conventu ubi sibi placuerit et Patres eum voluerint ${ }^{122}$, co może świadczyć o niesnaskach w klasztorze i próbie ich załagodzenia poprzez przeniesienie uwikłanego w spór zakonnika do innego klasztoru.

Znacznie więcej da się powiedzieć o wykształceniu poznańskich zakonników. $\mathrm{Z}$ zachowanych, choć niekompletnych, spisów lektorów wynika, że właściwie od samego początku istnienia klasztoru w Poznaniu funkcjonowała szkoła konwentualna, do której musieli obowiązkowo uczęszczać wszyscy obecni w klasztorze zakonnicy. W wieku XIV powstało tam również studium o charakterze partyku-

\footnotetext{
${ }^{120}$ Ibidem, s. $216 \mathrm{n}$.

${ }^{121}$ Akta, s. 95: [...] fr Stanislaus de conv. Posnaniensi in Copsiwnica et aliis locis occupando se cum meretricibus multa scandala commisit, per unum annum carceri adiudicamus.

${ }^{122}$ Zob. wyżej - przypis 113.
} 
larnym, w którym wykładano przedmioty wchodzące w skład tak zwanych sztuk (artes). Kiedy dokładnie szkoła ta powstała tego niestety nie wiemy, pewne jest jednak, że istniała ona w latach 30 -tych tego stulecia ${ }^{123}$. W wieku XV - świadczą o tym skierowania do wykładów zachowane w aktach kapituł prowincji polskiej, a także naukowa tytulatura niektórych zakonników - działała w Poznaniu partykularna szkoła teologiczna, do której uczęszczali na zajęcia zarówno bracia z miejscowego konwentu, jak i przybysze z innych klasztorów dominikańskich. Zakonnicy z Poznania wyjeżdżali także z wykładami i na studia poza swój konwent - do Krakowa i za granice kraju oraz prowincji, ale skala tych migracji nie była chyba zbyt wielka. Nie da się w każdym razie porównać ich liczby z podobnymi zestawieniami studentów dominikańskich z Krakowa, czy Wrocławia ${ }^{124}$.

Zdajemy sobie sprawę z tego, że nasze uwagi, a zwłaszcza podane wyżej spisy zakonników poznańskich muszą być weryfikowane i uzupełniane. Z całą pewnością w średniowiecznych źródłach uda się w przyszłości odnaleźć jeszcze wielu innych dominikanów, zamieszkujących klasztor w Poznaniu w okresie średniowiecza. Taka jest skądinąd specyfika badań prozopograficznych - rzadko udaje się wyczerpać temat związany z poszukiwaniem ludzi i jakże często (chciałoby się powiedzieć: na szczęście) możemy do już znanych nam postaci dodać nowe osoby. Mamy nadzieję, że uwagi zawarte w tym skromnym przyczynku do dziejów poznańskiego konwentu dominikanów staną się zaczątkiem następnych badań nad tym klasztorem.

\footnotetext{
${ }^{123}$ Trudno zgodzić się w propozycją J. W i e s i o $10 \mathrm{w}$ s k i e g o, Dominikanie w miastach. s. 249, który uważał, że lektorem sztuk w tym studium miał być już w początkach XIV wieku brat Dominik. Ten ostatni występuje co prawda w źródłach z tytułem lektora, ale nigdzie nie ma adnotacji o tym, że wykładane przezeń przedmioty wchodzą w zakres artium. W tej sytuacji Dominika należy uznać za zwyklego lektora szkoły konwentualnej i nie można łączyć jego osoby z powstaniem partykularnej szkoly sztuk.

${ }^{124} \mathrm{~K} l$ o c z o w s k i, passim.
} 